\begin{tabular}{l|l|l|l|l}
\hline Volume 1 & Issue 3 & December (2020) & DOI: 10.47540/ijsei.v1i3.69 & Page: $227-233$ \\
\hline
\end{tabular}

\title{
Anti-Defection Laws in Ethiopia: Is There Any Constitutional Room?
}

\author{
Leake Mekonen Tesfay \\ Aksum University, College of Social Sciences and Languages, Tigray, Ethiopia \\ Corresponding Author: Leake Mekonen Tesfay; Email: happyleake@gmail.com
}

\begin{tabular}{ll}
\hline A R T I C L E I N F O & A B S T R A C T \\
$\begin{array}{l}\text { Keywords: Anti-Defection Laws; } \\
\text { Constitutional Law; Parliamentary }\end{array}$ & $\begin{array}{l}\text { Anti-defection laws are laws by which members of parliaments (MPs) who changed } \\
\text { their party affiliation or voted against the position of their political faction or } \\
\text { independent MPs who joined a political party are forced to vacate their } \\
\text { parliamentary seat or prohibited from nomination as candidates of another political } \\
\text { peceived }: 27 \text { July } 2020\end{array} \quad \begin{array}{l}\text { party in the next election. The essence of anti-defection laws is restricting political } \\
\text { pevised }: 01 \text { December } 2020\end{array}$ \\
Accepted $: 05$ December 2020 & $\begin{array}{l}\text { parties' loss of majority in the parliament. Anti-defection laws are not uniformly } \\
\text { used. While many established democracies see parliamentary defection as a } \\
\text { manifestation of democracy, other jurisdictions with undeveloped democracies have } \\
\text { outlawed defection. In Ethiopia, the FDRE Constitution entitles MPs to be led by } \\
\text { the Constitution itself, peoples' will, and their conscience, not necessarily by their } \\
\text { party line. Accordingly, MPs can opine and vote contrary to the views of the } \\
\text { political party of their membership in parliamentary debates; they can even change } \\
\text { their party affiliation without risk of losing their parliamentary mandate. This makes } \\
\text { Ethiopia one of the countries without anti-defection laws. }\end{array}$ \\
\hline
\end{tabular}

\section{INTRODUCTION}

By anti-defection laws, it is meant laws by which MPs who switched from one political party to another or voted against the position of the political party of their membership after they secured their parliamentary seats as political party nominees in an election, or independent MPs who joined a political party after they secured a parliamentary seat as an independent candidate in an election are forced to renounce their parliamentary seat or prohibited from running in the next election as candidates nominated by another political party.

The application of anti-defection laws varies from one jurisdiction to another. While many countries, especially those with more established democracies do not have anti-defection laws, rather they consider parliamentary defection or voting against the position of one's political party as manifestations of the right to freedom of association and expression, and democracy; on the contrary, other jurisdictions, especially those with undeveloped or new democracies have resorted to enacting anti-defection laws to outlaw and preclude parliamentary defection (Janda, 2009; Nikolenyi, 2011).

This article attempts to examine the constitutional basis for anti-defection laws in Ethiopia. To this end, a review is made to the relevant constitutional provisions, related literature, and the experience of other jurisdictions, to establish an understanding of the essence of antidefection laws and to see if the FDRE Constitution has anti-defection clauses or allows the enactment of separate anti-defection laws. It is argued that the FDRE Constitution entitles MPs to be led by the Constitution itself, peoples' will, and their conscience, not necessarily by their party line. According to this, MPs in Ethiopia can opine and vote contrary to the views of the political party of their membership in parliamentary debates; they can even change their party affiliation without fearing the subsequent loss of their parliamentary mandate. Most importantly, any remedy, criminal or administrative, cannot be taken against an MP in this connection. This makes Ethiopia to be included in the menu of countries without anti-defection laws. 


\section{Materials AND Methods}

The research design used in writing this research article is a qualitative approach of desktop research type. Accordingly, qualitative data have been collected through the review of related literature pertinent to the meaning and nature, and application of anti-defection laws in different jurisdictions as well. With respect to the constitutional status of anti-defection laws in Ethiopia, a review has been made to the literature pertinent to the Ethiopian experience, although the literature available in this regard is scarce, and, more importantly, the relevant provisions of the Constitution of the Federal Democratic Republic of Ethiopia.

The data collected are analyzed by triangulating the data collected with respect to the Ethiopian experience in comparison with the lesson which can be drawn from comparative experience. What has to be made clear from the outset is that this research article does not examine the practice with respect to the loss of parliamentary mandate generally and anti-defection laws particularly in Ethiopia. It only assesses the thematic aspect of the matter.

\section{RESULTS AND DISCUSSION \\ Understanding Parliamentary Defection}

Giving it a plain meaning, parliamentary defection has been defined as an act by which "a Member of Parliament (MP) changes his or her party affiliation from one party group to another during a legislative period, or leaves the party to sit as an independent" (Goeke \& Hartmann, 2011, p. 263; Sotwal \& Agrawal, 2014). Parliamentary defection is also called party switching, floorcrossing, carpet crossing, and horse-trading (Janda; Goeke \& Hartmann; Sotwal \& Agrawal). As it will be made clear below, the definition of parliamentary defection is also understood in some jurisdictions to include cases where an MP votes opposite to the directions of the political party of his/her membership in parliamentary votes, without necessarily changing party affiliation (Janda).

The reasons why MPs switch from one political party to another and the forms partyswitching assumes may vary from one case to another. An MP may, individually, fall into a dilemma when the position of the political party of her/his membership differs from the preferences of his/her constituency. In such cases, the MP may choose his/her constituency's preferences and opt for the chance of re-election than choosing loyalty to the party's position and try to ensure his/her ability to rise to power within the party (Subramanian, 2008, cited in Janda). Goeke \& Hartmann (2011) have summarized the literature on the reasons why MPs switch parties into two. On the one hand, party-switching may come as a result of weak party institutionalization, i.e., lack of intraparty democracy, and strong personalism and patronage. Resulting from this, intraparty disputes may lead to party splitting in which the defeated faction secedes and collectively switches from the political party. On the other hand, MPs may also switch their party affiliation motivated by opportunities to parliamentary offices, positions in reelection, or "to increase the likelihood of achieving preferred policy outcomes" (Goeke \& Hartmann, 2011).

\section{The Essence of Anti-Defection Laws}

Parliamentary defections resulting from ideological (policy) differences are not considered problematic and are not the issues anti-defection laws are intended to handle (Janda). These, rather, are considered as manifestations of the freedom to expression and parliamentary discussion and debate embodied in the fabric of parliamentary democracy (Sotwal \& Agrawal). Anti-defection laws are concerned with tackling non-ideological defections in which MPs switch party affiliation, not because of ideological preferences rather for personal gain, i.e., in return for a promise for appointment for office by another party (Janda; Sotwal \& Agrawal). Such defections may lead to the creation of a new government hence for the defectors to be rewarded with positions in the new government (Janda). To tackle suck like solicited and opportunistic defections and to promote the stability of government parties, governments may enact antidefection laws (Janda; Goeke \& Hartmann).

Anti-defection laws are appealed to more in emerging democracies or non-democratic states than in established democracies which, resort to controlling party-switching with other intraparty rules than constitutional and/or legal regulation (Goeke \& Hartmann). Nikolenyi (2011) has reviewed world countries with constitutional antidefection clauses. Accordingly, of the 40 countries with constitutional anti-defection clauses, most are 
from non-democratic states and some new democracies, i.e., 24 countries from Africa, 9 countries from Asia, 5 countries from the Americas, 1 country from Europe, and 1 from the Middle East.

Similarly, Janda (2009) has assessed statutory anti-defection provisions in 193 world countries. Accordingly, of the 36 countries classified as olddemocracies, 5 countries (14\%); of the 54 countries classified as new-democracies, 13 countries (24\%); of the 58 countries classified as semi-democracies, 19 countries (33\%); and of the 45 countries classified as non-democracies, only 4 countries (9\%) have anti-defection provisions. Visible from the data, anti-defection laws are used more by the countries classified as semi-democracies and newdemocracies than the countries classified as olddemocracies. It is also visible that only 4 countries ( $9 \%$ ) of the countries classified as non-democracies have anti-defection laws. This would have been a disproof to the proposition that anti-defection laws are used more in non-democracies, semidemocracies, or new-democracies than in olddemocracies. However, many of the countries classified as non-democracies "even do not allow political parties" making the absence of antidefection provisions of no meaning.

In addition, New Zealand and South Africa had anti-defection statutes, but they have been abandoned. This strengthens the view that antidefection provisions are more common in emerging democracies than in established ones. The nondemocratic nature of anti-defection laws is also expressed in the fact that party leaders may use them to strengthen their undue control on party members and this may threaten parliamentary debates and discussions (Janda).

Variances in the Application of Anti-Defection Laws

Although anti-defection laws in different jurisdictions have similar objectives, i.e., promoting stability of government parties, their application varies in many respects. First, they vary with respect to the effect of defection. In many countries with anti-defection laws, defectors are forced to leave their parliamentary seats. According to Nikolenyi (2011), of the 40 countries included in his study, in the 39 countries, defectors are immediately expelled from their seats in the parliament, whereas Israel remains the exception. According to the Israeli anti-defection provision, defectors do not immediately lose their seats in the Knesset (Parliament). Rather, the effect of defection is deferred until the time for the next election comes; defectors cannot run as candidates in the next election to enter the next Knesset.

Second, anti-defection laws vary with respect to the issue of whether defection covers only voluntary resignation from political party membership or includes expulsion. According to Nikolenyi (2011), of the 40 countries included in his study, in almost half of them, expulsion from political party membership leads to loss of parliamentary seat. In the case of India, a sui generis for itself, although expulsion was included in the meaning of defection in the draft of the 1985 anti-defection clause, it was excluded from the final version of the law. In India, an MP expelled from political party membership incurs disqualification from his/her parliamentary seat only if $\mathrm{s} /$ he joined another political party.

The Indian Supreme Court has decided that an MP elected to the Parliament as a political party candidate is required to continue as a member of that political party, and even if expelled from his/her political party membership $\mathrm{s} / \mathrm{he}$ is considered a member of that political party for the purpose of the anti-defection clause in the Indian Constitution (G. Viswanathan The Hon'ble Speaker Tamil Nadu Legislative Assembly). However, if $\mathrm{s} /$ he joined another political party, even after $\mathrm{s} / \mathrm{he}$ has been expelled by the political party, s/he is considered to have voluntarily given up his/her membership in the political party which set up $\mathrm{him} / \mathrm{her}$ as a candidate and, therefore, is disqualified from his/her parliamentary seat.

Thirdly, anti-defection laws vary with respect to the treatment of parliamentary dissent. While many jurisdictions allow parliamentarians to freely vote even contrary to the position of their party whip, there are some countries that penalize parliamentarians for voting against the position of their political factions. According to Nikolenyi (2011), of the 40 countries included in his study, only 6 countries, i.e., Guyana, India, Pakistan, Bangladesh, Zimbabwe, and Sierra Leone penalize parliamentary dissent as defection.

In Israel, it is only voting contrary to the position of one's political faction in votes of confidence or no-confidence motion, in consideration of promises to be included in the list 
of candidates in the next election or any other position that is considered as defection (Israel's Constitution (Basic Law: The Knesset), Article 6A (b)). The inclusion of parliamentary dissent in the definition of defection is criticized as an undue limitation on parliamentary discussion and debate hence clawing deliberative democracy back. Khana and Shah (2012) have argued that the inclusion of parliamentary dissent in the definition of "defection" leading to disqualification of MPs in the Indian Constitution unduly limits MPs' freedom of expression and the right to dissent, which are expressions of democratic parliamentary discourse. And, they rightly recommend that the definition of defection should be limited to actual change of party affiliation by MPs.

\section{Jurisdictions Where Ant-Defection Laws Declared Unconstitutional}

As already stated above, anti-defection laws are more common in non-democratic states or in new democracies than in old and more established democracies. However, what has to be noted is also that anti-defection laws enacted by parliaments are not always validly accepted. On the contrary, there are cases where anti-defection laws are declared unconstitutional and void.

In Papua New Guinea's Organic Law on the Integrity of Political Parties and Candidates of 2003 (Section 57, 58, and 65), it was provided that an MP can resign from her/his membership in a political party only upon accepted grounds with written notice to the president of the political party specifying the reasons for his/her resignation. Resignation without accepted grounds was also provided as an offense against official duty (Section 57(3) and 68). Procedurally, upon receipt of the resignation notice, the president of the political party was required to send such a resignation notice to the registrar of political parties, which in turn was to send it to the Ombudsman for investigation and decision as to whether there are acceptable grounds for resignation or the member is guilty of resignation without accepted grounds (Section 59 and 60). Pending the investigation, the MP was required to remain a member of the political party from which $\mathrm{s} /$ he intended to resign (Section 61).

Moreover, it was provided for an MP's vote against the resolution of the political party of her/his membership in parliamentary votes, including in vote of confidence or no-confidence not to be counted (Section 65(1)(c) and 66). Independent MPs, who initially support the election of a prime minister were also required to vote in support of her/him if a vote on confidence or no-confidence motion is held during his/her term, in votes for a constitutional amendment, and votes for national budget (Section 70, 71, 71, 72 and 73). These provisions were developed to remedy repeated government failure due to defection by MPs and "vote of no confidence" against the government (Okole, 2012). Because, volatility of party alliances and vote of no confidence leading to failure of government have long been the features of Papua New Guinea's political system since its independence from Australian administration under United Nations trusteeship in 1975 (UNDPADMDESA, 2004).

These all provisions, however, have been declared unconstitutional. Papua New Guinea's Supreme Court has invalidated these provisions in its decision on the $7^{\text {th }}$ of July 2010 on the reason that they are unreasonable restrictions on constitutional democratic freedoms (Okole). Particularly, the Supreme Court stated that these provisions contravene the constitutionally guaranteed right to association and political party membership, right to hold public office and exercise public functions, and "powers, privileges and immunities of Members of Parliament" (Okole, pp. 2-4).

Decisions similar to that of Papua New Guinea's Supreme Court have also been given by constitutional courts in Benin and the Central African Republic. In Benin, the anti-defection provision was incorporated in the party law providing that a member of parliament elected for a political party who resigns his mandate for whatever reason, loses his seat within the institution concerned. He is immediately replaced by his substitute' (Article 45, quoted in Goeke \& Hartmann). The Constitutional Court, however, declared this unconstitutional, on the ground that it represses the freedom of opinion and expression and violates "article 80 of the Constitution which prohibits any imperative mandate" (Agbodjan, 2009, cited in Goeke \& Hartmann).

Many constitutions such as that of France, Bulgaria, Cote d voire, Croatia, Denmark, Mali, Poland, Republic of Korea, Romania, Senegal, Equatorial Guinea, and Spain prohibit imperative 
representation. On the contrary, in countries where parliamentary mandate is considered imperative such as Norway, Chile, Cuba, Finland, Guatemala, Italy, Senegal, and Sweden MPs are either not allowed to resign (as in the case of Norway and Chile), or allowed with authorization of the assembly or allowed only for legal impediment (as in the case of Finland) (Hulst, 2000). Similarly, the Constitutional Court of Central African Republic has ruled that "an MP represent[s] his electorate and not his party" nullifying anti-defection provisions and claims (Africa Research Bulletin, 1999, cited in Goeke \& Hartmann).

\section{Anti-Defection Laws in Ethiopia: Is There Any Constitutional Room?}

Having seen the essence of parliamentary defection and anti-defection laws with the experience of different countries, let us see now the Ethiopian case with respect to the existence or nonexistence of ant-defection laws. In this regard, the relevant provision in the FDRE Constitution (Article 54(4)) provides that "[m]embers of the House [of Peoples Representatives] are representatives of the Ethiopian People as a whole". Moreover, it provides that MPs are led by the Constitution itself, "the will of the people", and their conscience (Article 54(4)). It becomes clear from this constitutional provision that MPs are required to work as representatives of the Ethiopian People as a whole, not only for the people of the constituency where they were elected and/or for the political party of their membership. Similar provisions for general representation are also included in constitutions such as that of France, Belgium, and Turkey (Hulst).

More importantly, this constitutional provision enables MPs elected as political party nominees to vote for what they believe is constitutional and serves the public interest irrespective of what position may be held and what direction may be given by the political party of their membership or by the party whip authorized to represent the views of the government party in the parliament. Similarly, the Constitution (Basic Law) of Germany provides that "members of the Bundestag shall not be bound by any order or instruction and shall act according to their conscience" (Hulst, p. 8). Therefore, the FDRE Constitution did not have antidefection clauses. That is why Goeke \& Hartmann
(2011) have included Ethiopia in the list of African countries which do not have ant-defection laws.

The FDRE Constitution also precludes the enactment of anti-defection legislation. Because, similar to the decision of the Constitutional Court of Central African Republic we discussed above, the FDRE Constitution provides that, MPs once elected are representatives of the Ethiopian People as a whole not of the political party that nominated them as candidates for the election. Accordingly, if there appears a conflict between constitutional principles and political party views and policies, an MP should be abided by the constitutional principles not by the party views, and this does not force an MP to lose his/her parliamentary seat, although may be removed from the political party's membership (Seeye, 2010). Therefore, the Ethiopian Parliament cannot enact an anti-defection law to force MPs to leave their parliamentary seat for terminating their political party membership or voting against the position of the government party to which they are members. In addition, MPs are immune from any criminal prosecution or any administrative remedy on the account of votes they cast or opinions they air in parliamentary discussions and debates (FDRE Constitution, Article 54(5)). This protects MPs from any form of anti-defection attacks.

The only case an MP may lose his/her parliamentary mandate is if and only if the people in the constituency where the MP was elected lose confidence in him/her (FDRE Constitution, Article 12(3) \& 54(7)). There are countries such as Gabon, the Lao People's Democratic Republic, the Philippines, and Zambia which allow for a recall of an MP either by the electorate or the political party that nominated him/her (Hulst, 2000). Hulst has mistakenly included the Ethiopian system together with these systems. However, in Ethiopia, at least theoretically constitutionally speaking, it is only the people who elected him/her that can recall an MP back, not the political party that nominated him/her for the election. Therefore, parliamentarians in Ethiopia cannot be forced to resign from their parliamentary seat or be prohibited from being nominated and running as candidates of another political party for future (next) elections on the ground that they have changed their political party affiliation or voted against the resolution of their political faction in parliamentary discussions and votes. 


\section{CONCLUSION}

Despite the constitutional ban against antidefection laws, there are practices, which this article did not handle, which make the issue of antidefection laws in the Ethiopian constitutional system a research agenda. One can remember the decision of the Cassation Bench of the Federal Supreme Court in Unity for Justice and Democracy Party $v$ Blue Party (Federal Supreme Court Cassation Decisions, Vol. 18, File No.112091) in which the Court, having a reference to the antidefection clause in the Israeli Constitution, decided that political party members even those who are non-MPs cannot withdraw from their political party membership, and take new membership in and be nominated as candidates for an election by another political party without a written withdrawal notice to the political party from which they withdraw.

Whether or not the political practice adheres to the constitutional principles is seen in times of critical political disputes, not in okay times when political rivalries are absent. In 2001, where the TPLF faces an intraparty crisis, there are complaints that MPs from the federal parliament and from regional state councils were expelled from their parliamentary seats following their expulsion (or resignation) from their political party membership in the TPLF (Seeye; Gebru, 2015).

Recent political developments, among which the coming of the Ethiopian Prosperity Party (EPP) as the successor of the former Ethiopian Peoples' Revolutionary Democratic Front (EPRDF) and TPLF's outright opposition for this is important, seem to show that the unanimity and party cohesion which have been symbols of the Ethiopian parliament for many years to pass will not continue. These all seem to create concerns of possible conflict between the demands to concentration of power on the one hand and demands for parliamentary freedom on the other hand. And possible eviction of MPs following these may make the issue of political defection and anti-defection laws particularly and loss of parliamentary mandate generally areas of research interest more in the future.

\section{REFERENCES}

Csaba Nikolenyi (2011), Constitutional Sources of Party Cohesion: Anti-Defection Laws Around the World, (Paper prepared for delivery at the Oslo-Rome Workshop on Democracy, November 7-9, 2011).

Electoral Law of Ethiopia Amendment

Proclamation No. 532/2007, Fed. Neg.

Gazzeta, Year 13, No. 54.

G. Viswanathan v The Hon'ble Speaker Tamil Nadu Legislative Assembly, Madras [1996] INSC 132 (24 January 1996).

Gebru Asrat, Sovereignty and Democracy in Ethiopia (in Amharic)(2015).

Henry Tadap Okole, A Critical Review of Papua New Guinea's Organic Law on the Integrity of Political Parties and Candidates: 20012010 (Australian National University, SSGM Discussion Paper 2012/5).

Israel's Constitution (Basic Law: The Knesset) of 1958 (with Amendments through 2013).

Kartic Khanna \& Dhvana Shah. (2012). Anti-

Defection Law: A Death Kneel to Parliamentary Dissent? 5 Nujs Law Review 103 (January-March, 2012)

Kenneth Janda. (2009). Laws Against Party

Switching, Defecting, or Floor-Crossing in National Parliaments, (The Legal Regulation of Political Parties Working Paper 2).

Leake Mekonen Tesfay. (2018). The Freedom to Withdraw From Political Party Membership under the Ethiopian Law: A Case Comment, Haramaya Law Review, Vol. 7.

Leake Mekonen Tesfay. (2017). The Right to Political Party Membership in Ethiopia: On the Freedom to Join and Resign, Mizan Law Review, Vol. 11, No. 2.

Marc Van der Hulst. (2000). The Parliamentary Mandate: A Global Comparative Study (Geneva: Inter-Parliamentary Union).

Martin Goeke \& Christof Hartmann. (2011). The regulation of party switching in Africa, Journal of Contemporary African Studies, 29:3.

Organic Law on the Integrity of Political Parties and Candidates 2003, Independent State of Papua New Guinea, Certified on 15/10/2003.

Proclamation to make the Electoral Law of Ethiopia Conform with the Constitution of the Federal Democratic Republic of Ethiopia, No. 11/1995 
Saurabh Sotwal \& Tanmay Agrawal. (2014). Anti

Defection Laws in India, International

Journal of Research and Analysis, Vol., 1, Issue 3.

Seeye Abraha. (2010). Freedom and Justice in Ethiopia (in Amharic)(Signature Book Printing).

The Ethiopian Electoral, Political Parties Registration and Election's Code of Conduct Proclamation No. 1162/2019, Fed. Neg. Gazzetta, $25^{\text {th }}$ Year, No. 97.

United Nations, Division for Public Administration and Department of Management (DPADM) Department of Economic and Social Affairs (DESA) (March 2004), Independent State of Papua New Guinea: Public Administration Country Profile.

Unity for Justice and Democracy Party v Blue Party, (Federal Supreme Court: Federal Supreme Court Cassation Decisions, Vol. 18, 421-435, File No. 112091 (06 May 2015). 